\title{
Cytotoxic Effect of the Locally Isolate Lactococcus lactis Cell Wall Proteins on Tumor Cell Lines
}

\author{
Moyassar B. H. Al-Shaibani*1 ${ }^{*}$, Ali Abbdul-Rahman T. Al-Shekhly ${ }^{* *}$ \\ and Mohammad R. Abdul-Majeed*** \\ * Department of Biotechnology, College of Science, University of Al-Nahrain, Baghdad-Iraq. \\ ** Nanotechnology and Advanced Materials Research Centre, University of Technology, Baghdad-Iraq. \\ *** Deceased. \\ ${ }^{1}$ E-mail: moyassarbasil@yahoo.com.
}

\begin{abstract}
This project was conducted to study the activity of cell wall components present in one of a human microflora which is Lactococcus lactis on $A M N-3$ and Hep-2 tumor cell lines in vitro. Twenty samples of dairy products (bucolic sour yoghurts, pasteurized milk and raw milk) were collected; nine isolates of Lactococccus were isolated by propagating in MRS broth medium followed by subjecting the isolates to microscopic, cultural, physiological and biochemical tests. The isolates were grown in $M 17$ broth medium, at $37^{\circ} \mathrm{C}$ for $6 \mathrm{hrs}$ followed by extraction cell wall proteins using sonication method followed by estimation the concentrations of extracted proteins depending on standard curve of bovine serum albumin. The cytotoxic activity of different concentrations was studied on $A M N-3$ and Hep-2 tumor cell lines for three incubation periods (24, 48 and $72 \mathrm{hrs}$ ) in addition to normal rabbit embryo fibroblast ( $R E F)$ cell line for $72 \mathrm{hrs}$ only. The results showed the presence of four isolates belong to the genus Lactococcus lactis. The result showed a clear cytotoxic activity of these crude extracts with high significances on these tumor cell lines during the three incubation periods, suggesting that the cytotoxic effect of $C W P$ is a dose and time dependent, but on $R E F$ cell line, there is no significant effect reported. It is concluded that $C W P$ of $L$. lactis may possess some specificity in cytotoxicity on cancer cells but not on normal cells.
\end{abstract}

Keywords: AMN-3, Hep-2, L. lactis, cell line, Cytotoxicity and REF.

\section{Introduction}

The intestinal flora is a complex ecosystem consisting of over 400 bacterial species that greatly outnumber the total number of cells making up the entire human body. These metabolically active bacteria reside close to the absorptive mucosal surface and are capable of a remarkable repertoire of transforming chemical reactions. The esophagus has a flora similar to that of the pharynx [1]. The empty stomach is sterile due to gastric acid. The normal flora of the duodenum, jejunum and upper ileum is scanty but the large intestine is very heavily colonized with bacteria among which are; Bacteriodes (mainly members of the fragilis group which outnumber Bacteroides fragilis itself), Bifidobacteria, Anaerobic cocci, E. coli, Streptococcus faecalis, Clostridia, Lactobacilli and less common inhabitants; Klebsiellaspp., Proteus spp., Enterobacter spp. and Pseudomonas aeruginosa. The intestinal flora can be thought of as a chemical factory with massive levels of active enzymes. All rapidly growing bacterial species in the small intestines produce metabolic by-products that can be absorbed. Some of the absorbed products are utilized for energy immediately in the epithelial cells of the gut; others may be acted upon by the detoxification systems in the liver; while others are passed [2].

The enteric flora comprises approximately $95 \%$ of the total number of cells in the human body and can elicit immune responses while protecting against microbial pathogens. The beneficial role of the normal flora is the prevention of other more pathogenic bacteria from gaining a foothold in the body. The gut bacteria seem to be responsible for the normal structure and function of the intestine: they degrade mucin, epithelial cells and carbohydrate fiber and their metabolism 
produces vitamins, especially vitamin $\mathrm{K}$ [3]. However, the resident bacterial flora of the gastrointestinal tract may also be implicated in the pathogenesis of diseases such as inflammatory bowel disease (ulcerative colitis and Crohn disease). Any compound taken orally, entering the intestine through the biliary tract or by secretion directly into the lumen is a potential substrate for bacterial transformation. So the colonic microflora is important to health [4]. Since the 1980s, many efforts have been made to better understand the molecular basis of LAB technological properties and to obtain better control of industrial processes involving LAB. This knowledge has led researchers to investigate their potential use for new applications, such as the production of heterologous proteins in bioreactors, in fermented food products or directly in the digestive tract of humans and other animals. Some LAB used as probiotic strains, naturally exerts a positive action in lactose-intolerant consumers by providing $B$ galactosidase in the gut [5]. Besides such natural benefits, another and innovative application of LAB is the antitumor activity to supplement pancreatic and gastrointestinal deficiency in humans [6]. On the strength of those investigations, the present study was proposed for isolation and identification of the species Lactococcus lactis that may possess antitumor activity. Extraction of cell wall associated proteins $(C W P)$ followed by in vitro study of the effect of these $(C W P)$ on the growth of $A M N-3$ and Hep-2 tumor cell lines and normal rabbit embryo fibroblast cell lines $(R E F)$.

\section{Materials and Methods Samples Collection}

Twenty samples of dairy products (bucolic sour yoghurts, pasteurized milk and raw milk) were collected in sterile containers from local markets in Baghdad governorate, followed by propagation the isolates by inoculating test tubes containing MRS broth medium with $1 \%$ of each sample and incubated at $37{ }^{\circ} \mathrm{C}$ for $24 \mathrm{hrs}$ under anaerobic conditions.

\section{Isolation of Lactic Acid Bacteria}

Lactic acid bacteria were isolated according to Harrigan and MacCance [7], serial dilutions were performed, followed by streaking on MRS agar plates containing 1\% calcium carbonate $\left(\mathrm{CaCO}_{3}\right)$, then incubated at $37^{\circ} \mathrm{C}$ for $24 \mathrm{hrs}$. After that, a loop touch of the growth was transferred to MRS broth and preserved.

\section{Identification of Lactococcus lactis}

The suspected LAB isolates were identified by the following tests:

\section{Microscopic Examination}

A loop full of each isolates culture was fixed on a microscopic slide, and then stained by Gram stain to examine cell shape, Gram reaction, grouping and spore forming phenomena [8].

\section{Biochemical Tests}

The biochemical tests used to identify the locally isolate L. lactis are gelatinase test, catalase test, acid production and clot formation, production of ammonia from arginine, carbohydrates fermentation, growth in $4 \%$ and $6.5 \% \mathrm{NaCl}$, growth in different $\mathrm{pH}$, growth at different temperature and growth in $(0.1 \%)$ methylene blue [9].

\section{Extraction of Bacterial Cell Wall Proteins}

Cell wall proteins of locally isolated $L$. lactis were extracted by growing them in M17 broth and cells harvested by centrifugation at $11000 \mathrm{rpm} 20 \mathrm{~min}$. Cells were washed with $30 \mathrm{mM}$ Tris hydrochloride $\mathrm{pH}$ 8.1, resuspended in $0.4 \mathrm{ml}$ of cold $20 \%$ sucrose $-30 \mathrm{mM}$ Tris hydrochloride $\mathrm{pH} 8.1$, and treated with $1 / 10$ volume of lysozyme $1 \mathrm{mg} / \mathrm{ml}$ in $0.1 \mathrm{M}$ EDTA pH 7.3 for $30 \mathrm{~min}$ at $4{ }^{\circ} \mathrm{C}$ and disrupted by sonication (six bursts of $1 \mathrm{~min}$ each) in ice, using a Sanyo MSE Soniprep 150. Debris and unbroken cells by centrifugation at 2,000 rpm for $10 \mathrm{~min}$, an aliquot $1 / 4$ volume of the extract was subjected to ultracentrifugation in a Beckman 70.1 Ti rotor for $2 \mathrm{hrs}$ at $15,000 \mathrm{rpm}$ at $4^{\circ} \mathrm{C}$, and the resulting supernatant was used as the cytoplasmic fraction. The total membrane pellet was washed twice with $30 \mathrm{mM}$ Tris

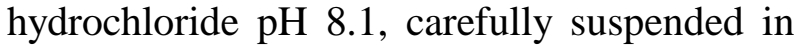
$20 \mathrm{ml}$ of $0.5 \%$ sodium lauryl sarcosinate, and shaken for $1 \mathrm{hr}$ at room temperature. The sample was centrifuged as before, and the supernatant was sterilized through $0.2 \mu \mathrm{m}$ pore-size filter units. Aliquots were stored at $20^{\circ} \mathrm{C}$ until required [10]. 


\section{Control (II) Preparation}

It was prepared by mixing $30 \mathrm{mM}$ Tris hydrochloride $\mathrm{pH} 8.1,3 \mathrm{mM}$ EDTA $\mathrm{pH} 7.3$ and $0.5 \%$ sodium lauryl sarcosinate, sterilized by autoclaving, cooled and followed by the addition of lysozyme $1 \mathrm{mg} / \mathrm{ml}$ which was previously sterilized by filtration.

\section{Quantitative Estimation of Proteins}

Protein concentration was estimated according to Bradford method by using Commassie blue G-250 and Bovine serum albumin $(B S A)$ to determine standard curve and estimate protein in concentrated filtrate [11].

\section{Standard Curve of Bovine Serum Albumin}

Bovine serum albumin (BSA) solution was prepared by dissolving $0.1 \mathrm{~g}$ of $B S A$ in a quantity of DW and the volume was completed to $100 \mathrm{ml}$ DW. Different concentrations of BSA $(2,4,7,10,14,16$ and $20 \mu \mathrm{g} / \mathrm{ml}$ ) were prepared and plotted [11].

\section{Estimation of Extracted Proteins}

The same steps followed in standard curve were used to determine the protein in concentrated filtrate by taking $20 \mu \mathrm{l}$ from each extract.

\section{Viable Cell Count}

Cells count were performed according to Freshney [12], using trypan blue dye, dead cells take up the dye making them easily distinguished from viable cells which counted by Neubauer chamber.

\section{Inhibition Assay}

The procedure below was depending on cytotoxicity testing mentioned in Freshney [12], which was applied for both $A M N-3$ and Hep-2 cell lines and rabbit embryo fibroblast $(R E F)$ which were obtained from Iraqi centre for cancer and medical genetic research. Cell suspension was well mixed and treated with both extracts poured into 96 flat bottom well microtiter plate and incubated at $37{ }^{\circ} \mathrm{C}$ for $72 \mathrm{hrs}$ in an incubator supplemented with (5\%) $\mathrm{CO}_{2} .50 \mu \mathrm{l} /$ well of neutral red dye were added and incubated again for $2 \mathrm{hrs}$. The results were read by ELISA reader at $492 \mathrm{~nm}$.

\section{Statistical Analysis}

The results were statistically analyzed to determine the significance effect among the concentrations of both extracts and their effect on tumor cell line and normal cells. The comparison between groups has based on analysis of variance test (ANOVA), while the significance differences based on Duncan's test [13].

\section{Results and Discussion}

The colonies of some isolates on MRS agar by pour plate were circular, white to yellow in color some of which were gray, smooth, mucous, bright and convex, Table (1). These characteristics were the same to those observed when pure culture was obtained using streaking method. It was observed that the growth of LAB on MRS agar was heavier than their growth on SL medium this may be due to the high ratio of sodium acetate and high acidity [14].

Also, there were other isolates their colonies characterized by different shapes (fusiform, ovoid and circular) white to pale in color, soft with smooth edges, non bright and some of which were convex. Such cultural characteristics are concerned with those of the colonies of the genus Lactobacillus [15].

Microscopic examination after Gram staining showed that some suspected cells were spherical, tend to be ovoid, and grouped in pairs, tetrads and short chains, Gram positive and non spore forming, Table (1), these results are supported by those of $\mathrm{El}$ Soda et al., [16] when they isolated 237 isolate of L. lactis among a total of 2000 isolates of LAB obtained from traditional Egyptian dairy products (different types of raw milk, ras, domiatti and kareish cheese, mish, cream, butter and fermented milk) obtained from different regions in Egypt.

Also, it was observed that the other isolates that may be belong to the genus Lactobacillus characterized as long curved rods, arranged in short and long chains (3-8) cells and some of which were single and in pairs, Gram positive and non spore forming.

Depending on the results of the cultural and microscopic tests, nine isolates may be belonging to the genus Lactococcus referred to as (Lc1, Lc2, Lc3, Lc4, Lc5, Lc6, Lc7, Lc8 and Lc9) and the other tested isolates may be 
belonging to the genus Lactobacillus. The abundance of the genus Lactococcus in dairy and dairy products is reasonable because they possesses proteinase enzyme system encourage them to grow in milk and its products [17].

Since the present study focused on studying the effect of the crude extract of the genus Lactococcus on tumor cell lines, so we restricted the biochemical tests on these suspected isolates ignoring the others.

Table (1)

Morphological and Cultural Taxonomic Characteristics of the suspected isolates.

\begin{tabular}{||l||c||}
\hline \multicolumn{1}{|c|}{ Characteristics } & Results \\
\hline \hline 1- Gram stain & G +ve \\
\hline 2- Cell shape & Spherical to oval \\
\hline \hline 3- Grouping & $\begin{array}{c}\text { Single, in pairs and } \\
\text { short chains }\end{array}$ \\
\hline \hline $\begin{array}{l}\text { 4-Colony shape on } \\
\text { MRS and SL agar }\end{array}$ & $\begin{array}{c}\text { Circular, small, } \\
\text { regular, convex with } \\
\text { smooth edges }\end{array}$ \\
\hline \hline 5- Motility & Non motile \\
\hline $\begin{array}{l}\text { 6- Growth under } \\
\text { aerobic conditions }\end{array}$ & + \\
\hline $\begin{array}{l}\text { 7- Growth under } \\
\text { anaerobic conditions }\end{array}$ & + \\
\hline
\end{tabular}

(+): Presence of Growth.

Biochemical characteristics shown in Table (2) demonstrated that each of the nine isolates were catalase negative since no bubbles were observed after addition of hydrogen peroxide, gelatinase negative, and the isolates (Lc1, Lc4, Lc5 and Lc8) produced ammonia from arginine due to the presence of arginine deiminase (AD) which is one of three enzymes that comprise the $\mathrm{AD}$ system, $\mathrm{AD}$ catalyzes the conversion of L-arginine to citrulline, with the concomitant production of ammonia [18]. Also these four isolates have grown in $0.1 \%$ methylene blue with reduction of dye with tenuous growth in $4 \% \mathrm{NaCl}$ while the growth was lacking in $6.5 \% \mathrm{NaCl}$ and $45^{\circ} \mathrm{C}$ and produced acid and formed clot in litmus milk causing the lowering of $\mathrm{pH}$ from 6.5 to 4.5, while other isolates (Lc2, Lc3, Lc6, Lc7 and Lc 9) did not produce ammonia from arginine due to the stability of the orange color of the medium, and lacked the ability to grow in $4 \% \mathrm{NaCl}$ as well as inability to grow in $0.1 \%$ methylene blue, also, all isolates taken part in their inability to grow at $45^{\circ} \mathrm{C}$ and $\mathrm{pH}$ 9.5 but have grew at $\mathrm{pH} 9$, facultative anaerobic since it had the ability to grow under aerobic and anaerobic conditions and can grow at $\left(10-40^{\circ} \mathrm{C}\right)$, these results are in agreement with taxonomic characteristics of the genus Lactococcus which were mentioned by Elsoda, et al., [16].

In order to differentiate the nine isolates of Lactococcus species, carbohydrates fermentation test was performed. The isolates were different in their ability to ferment the carbohydrates source used. The isolates $(\mathrm{Lc} 2$, Lc3, Lc6 Lc7 and Lc9) which fermented (glucose, sucrose, lactose, mannose, mannitol, galactose, maltose and raffinose) but varied in their ability to ferment arabinose and xylose were identified as Lactococcus raffinolactis. While the isolates (Lc1, Lc4, Lc5 and Lc8) vary in their ability to ferment xylose while unable to ferment arabinose and raffinose but have fermented the other used sugars were identified as L. lactis [19].

According to the results above, the overall result was nine isolates of Lactococcus; five of them (Lc2, Lc3, Lc6 Lc7 and Lc9) were identified as Lactococcus sp. Raffinolactis and the others (Lc1, Lc4, Lc5 and Lc8) were identified as Lactococcus sp. lactis. Our study focused on studying the effect of the crude extracts of the genus Lactococcus sp. lactis ignoring the species raffinolactis. 
Table (2)

Biochemical tests of the locally isolated Lactococcus Isolates.

\begin{tabular}{|c|c|c|c|c|c|c|c|c|c|c|c|c|c|c|c|c|c|c|}
\hline \multirow[b]{2}{*}{ Isolate } & \multirow{2}{*}{$\begin{array}{c}\text { Catalase } \\
\text { Test }\end{array}$} & \multirow{2}{*}{$\begin{array}{c}\text { Gelatinas } \\
\text { Test }\end{array}$} & \multirow{2}{*}{$\begin{array}{c}\mathrm{NH}_{3} \\
\text { product. } \\
\text { from } \\
\text { Arginin }\end{array}$} & \multirow{2}{*}{$\begin{array}{c}\text { Growth } \\
\text { in litmus } \\
\quad \text { Milk }\end{array}$} & \multicolumn{3}{|c|}{ Growth at } & \multirow{2}{*}{$\begin{array}{c}\text { Growth } \\
\text { in } 1 \% \\
\text { methylene } \\
\text { blue }\end{array}$} & \multicolumn{10}{|c|}{ Acid Production from } \\
\hline & & & & & $\begin{array}{l}10 \\
{ }^{10} \mathrm{C}\end{array}$ & $\begin{array}{l}40 \\
{ }^{\circ} \mathrm{C}\end{array}$ & $\begin{array}{l}45 \\
{ }^{\circ} \mathrm{C}\end{array}$ & & Glu & Suc & Lac & Mans & Manl & Arab & $x y l$ & Gal & Mal & Raf \\
\hline Lc1 & - & - & + & + & + & + & - & + & + & + & + & + & + & - & + & + & + & - \\
\hline $\mathrm{Lc} 2$ & - & - & - & + & - & + & - & - & + & + & + & + & + & - & + & + & + & + \\
\hline Lc3 & - & - & - & + & - & + & - & - & + & + & + & + & + & - & + & + & + & + \\
\hline Lc4 & - & - & + & + & + & + & - & + & + & + & + & + & + & - & + & + & + & - \\
\hline Lc5 & - & - & + & + & + & + & - & + & + & + & + & + & + & - & - & + & + & - \\
\hline Lc6 & - & - & - & + & - & + & - & - & + & + & + & + & + & - & + & + & + & + \\
\hline Lc7 & - & - & - & + & - & + & - & - & + & + & + & + & + & + & + & + & + & + \\
\hline Lc8 & - & - & + & + & + & + & - & + & + & + & + & + & + & - & + & + & + & - \\
\hline Lc9 & - & - & - & + & - & + & - & - & + & + & + & + & + & + & - & + & + & + \\
\hline
\end{tabular}

Glu: glucose. Suc: sucrose. Lac: lactose. Mans: mannose. Manl: mannitol.

Arab: arabinose. Xyl: xylose. Gal: galactose. Mal: maltose. Raf: raffinose.

\section{Extraction and Purification of Extracted Proteins}

The quantity of extracted $C W P$ was $18.382 \mu \mathrm{g} / \mathrm{ml}$. partial purification of the proteins was carried out by precipitation with ammonium sulphate. In addition to purification, this step leads to considerable lose in the concentrations of extracted protein which was $16.493 \mu \mathrm{g} / \mathrm{ml}$.

\section{Effect of Cell Wall Protein (CWP) on AMN- 3 cell line}

The cytotoxic effect of the CWP in the growth of $A M N-3$ cell line has started with high significance difference $(\mathrm{P} \leq 0.001)$ at the concentration $0.625 \mu \mathrm{g} / \mathrm{ml}$ toward the higher concentrations when compared with the control I $(A M N-3$ cell line treated with serum free medium "SFM") during the incubation period $24 \mathrm{hrs}$, Table (3). When the incubation period was $48 \mathrm{hrs}$, cytotoxic effect of this crude extract with high significance difference $(\mathrm{P} \leq 0.001)$ has started at the concentration $0.625 \mu \mathrm{g} / \mathrm{ml}$ toward the higher concentrations when compared with control. While during the incubation period $72 \mathrm{hrs}$, it was found that the cytotoxic effect of this crude extract has began with high significant difference $(\mathrm{P} \leq 0.001)$ at the concentration $0.312 \mu \mathrm{g} / \mathrm{ml}$ toward the higher concentrations when compared with control I and with high significant effect $(\mathrm{P} \leq 0.0002)$ when compared with control II $(A M N-3$ cells treated with lysozyme $1 \mathrm{mg} / \mathrm{ml})$. 
Table (3)

The effect of CWP on AMN-3 cell line.

\begin{tabular}{|c|c|c|c|c|}
\hline \multirow{2}{*}{ Group } & \multirow{2}{*}{ Conc. $(\mu g / m l)$} & \multicolumn{3}{|c|}{ O.D. Mean $\pm\left(S E \times 10^{-3}\right)$ at different incubation periods } \\
\hline & & After $24 \mathrm{~h}$ & After $48 \mathrm{~h}$ & After $72 \mathrm{~h}$ \\
\hline \multirow{6}{*}{ Treated } & 0.312 & $0.46267 \pm 5.363^{\mathrm{a}}$ & $0.45400 \pm 4.041^{\mathrm{a}}$ & $* 0.40400 \pm 3.510^{a}$ \\
\hline & 0.625 & $* 0.44100 \pm 5.294^{b}$ & $* 0.40100 \pm 8.082^{\mathrm{b}}$ & $0.38600 \pm 5.132^{\mathrm{a}}$ \\
\hline & 1.25 & $0.38500 \pm 6.108^{c}$ & $0.36700 \pm 3.215^{\mathrm{b}}$ & $0.33800 \pm 0.027^{\mathrm{b}}$ \\
\hline & 2.5 & $0.38000 \pm 7.551^{\mathrm{c}}$ & $0.31100 \pm 5.132^{b}$ & $0.32200 \pm 5.132^{\mathrm{c}}$ \\
\hline & 5 & $0.34100 \pm 7.765^{\mathrm{d}}$ & $0.30300 \pm 3.602^{b}$ & $0.22400 \pm 4.584^{\mathrm{d}}$ \\
\hline & 10 & $0.28700 \pm 7.095^{\mathrm{e}}$ & $0.26100 \pm 5.132^{\mathrm{c}}$ & $0.24200 \pm 0.035^{\mathrm{e}}$ \\
\hline \multicolumn{2}{|c|}{ Control I } & $0.46500 \pm 3.054^{\mathrm{a}}$ & $0.45600 \pm 4.162^{\mathrm{a}}$ & $0.43500 \pm 3.510^{\mathrm{a}}$ \\
\hline \multicolumn{2}{|c|}{ Control II } & $0.42800 \pm 4.041^{\mathrm{a}}$ & $0.42800 \pm 4.041^{\mathrm{a}}$ & $0.42800 \pm 4.041^{\mathrm{a}}$ \\
\hline
\end{tabular}

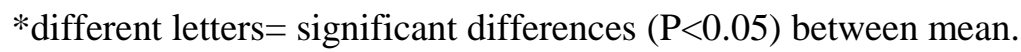

\section{Effect of Cell Wall Protein (CWP) on Hep-2 Cell Line}

At incubation period $24 \mathrm{hrs}$, the cytotoxic effect of $C W P$ with significant difference $(\mathrm{P} \leq 0.047) \quad$ was noted at concentration $1.25 \mu \mathrm{g} / \mathrm{ml}$ toward the higher concentrations when compared with the control I (Hep-2 cell line treated with $S F M$ ) and high significant difference $(\mathrm{P} \leq 0.001)$ when compared with the control II, Table (4). The cytotoxicity with high significant difference $(\mathrm{P} \leq 0.01)$ during the incubation period $48 \mathrm{hrs}$ has started at the concentration $0.625 \mu \mathrm{g} / \mathrm{ml}$ accompanied with an increase in cytotoxicity toward the higher concentrations when compared with the control I and high significant difference $(\mathrm{P} \leq 0.02)$ when compared with the control II. whereas at incubation period $72 \mathrm{hrs}$, cytotoxic effect with high significant difference $(\mathrm{P} \leq 0.001)$ has begun at the concentration $0.625 \mu \mathrm{g} / \mathrm{ml}$ toward the higher concentrations when compared with control I and high significant difference $(\mathrm{P} \leq 0.002)$ when compared with the control II.

Table (4)

The effect of CWP on Hep-2 cell line

\begin{tabular}{|c|c|c|c|c|}
\hline \multirow{2}{*}{ Group } & \multirow{2}{*}{ Conc. $(\mu g / m l)$} & \multicolumn{3}{|c|}{ O.D. Mean $\pm\left(S E x 1^{-3}\right)$ at different incubation periods } \\
\hline & & After $24 \mathrm{~h}$ & After $48 \mathrm{~h}$ & After $72 \mathrm{~h}$ \\
\hline \multirow{6}{*}{ Treated } & 0.312 & $0.39000 \pm 5.132^{\mathrm{a}}$ & $0.36333 \pm 5.785^{\mathrm{a}}$ & $0.36100 \pm 5.132^{\mathrm{a}}$ \\
\hline & 0.625 & $0.38000 \pm 6.714^{\mathrm{a}}$ & $* 0.35500 \pm 5.132^{b}$ & $* 0.32800 \pm 3.787^{\mathrm{b}}$ \\
\hline & 1.25 & $* 0.37800 \pm 4.041^{\mathrm{b}}$ & $0.34800 \pm 6.246^{\mathrm{c}}$ & $0.28900 \pm 5.132^{\mathrm{b}}$ \\
\hline & 2.5 & $0.35567 \pm 5.455^{\mathrm{b}}$ & $0.30000 \pm 6.656^{\mathrm{d}}$ & $0.28833 \pm 3.481^{\mathrm{b}}$ \\
\hline & 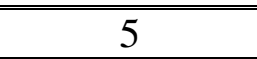 & $0.32567 \pm 0.018^{\mathrm{c}}$ & $0.28800 \pm 5.132^{\mathrm{d}}$ & $0.26067 \pm 0.011^{\mathrm{c}}$ \\
\hline & 10 & $0.31733 \pm 0.035^{\mathrm{d}}$ & $0.22500 \pm 5.132^{\mathrm{e}}$ & $0.16500 \pm 5.686^{\mathrm{d}}$ \\
\hline \multicolumn{2}{|c|}{ Control I } & $0.39200 \pm 3.602^{\mathrm{a}}$ & $0.36700 \pm 5.565^{\mathrm{a}}$ & $0.36300 \pm 4.041^{\mathrm{a}}$ \\
\hline \multicolumn{2}{|c|}{ Control II } & $0.35700 \pm 3.602^{a}$ & $0.35700 \pm 3.602^{a}$ & $0.35700 \pm 3.602^{\mathrm{a}}$ \\
\hline
\end{tabular}

*different letters $=$ significant differences $(\mathrm{P}<0.05)$ between mean.

Our findings consistent to those gained by Degnan et al., [21] who showed that Streptococcus pyogenes (group A Streptococcus) cell extracts (CE) at concentrations above $0.5 \mu \mathrm{g} / \mathrm{ml}$ among the used concentrations $(0,0.008,0.04,0.2,0.5$,
1.0 , and $5.0 \mu \mathrm{g} / \mathrm{ml}$ ) consistently caused potent inhibition of T-cell proliferation in vitro during three days incubation period. On other hand, Streptococcal acid glycoprotein (SAGP); which possesses between 31.5 and $39.0 \%$ amino acid identity with arginine deiminase 
(AD) which has been well documented as having anti-proliferative activity against a range of tumor cell lines, including murine fibrosarcoma Meth A cells, human HL60 cells, murine embryonic cells (BALB/3T3), HeLa cells, and murine leukemic L1210 cells [22]. Also, the action of AD will lead to a depletion of L-arginine in growth media, and may be in the absence of L-arginine cells are simply unable to synthesize new proteins, thus inhibiting growth and proliferation. Since L. lactis is a genus of group A streptococci so their inhibitory effect in the growth of tumor cell lines may be attributed to this active compound (SAGP) [21]. Also, bacterial products seem to restrict access of lipopolysaccharides (LPS) to CD14 receptors on monocytes/macrophages this is associated with lowering of NF kappa B signalling in immune cells and hostile of TNF- $\alpha$ secretion. Although intestinal macrophages do not express CD14 under basal conditions, their expression is upregulated under inflammatory conditions underlining the potential beneficial effect of probiotic bacteria under these conditions [23]. Another interpretation of our result that purified lactococcal cell walls have antitumour activities in that the cell wall induces activation of phagocytes to destroy growing tumor cells. Bifidobacteria probiotics reduced colon carcinogenesis induced by $1,2-$ dimethylhydrazine in mice when used with fructo-oligosaccharides and inhibited liver and mammary tumors in rats [24]. This effect may be attributed to the active compounds involved in construction of bacterial cell wall. Lipoteichoic acids of Gram positive bacteria such as bifidobacteria and LAB possess high binding affinity for epithelial cell membranes and can also serve as carriers for other antigens, binding them to target tissues, where they provoke an immune reaction, also, there are other bacterial metabolic products which possess immunomodulatory properties include: endotoxic lipopolysaccharide, peptidoglycans, and lipoteichoic acids [3].
Effect of the $C W P$ of the Locally Isolated $L$. lactis on Normal Rabbit Embryo Fibroblast $(R E F)$ Cell Line

Statistical analysis has showed that there is no significant difference $(\mathrm{P} \leq 0.039)$ for each concentration of these crude extracts when compared with both control I and control II indicating that these crude extracts have no lucid effect on the growth of $R E F$ cell line after incubation period for $72 \mathrm{hrs}$. The compounds of the secondary metabolites characterized by their selectivity in their effect on tumor cells, so a comparison was made between the effects of $C W P$ on $A M N-3$ and Hep-2 tumor cell lines and their effect on normal cells $(R E F)$ at incubation period $72 \mathrm{hrs}$, considering the later as control. It was observed that there is an obvious cytotoxic effect for these extracts in the growth of these cell lines comparing with control $(R E F)$ with variation in inhibition intensity of each crude extract, Fig.(2).

It was observed that there is an obvious cytotoxic effect for these extracts on both tumor cell lines $(A M N-3$ and Hep-2). In contrast, there was no effect or slight effect without significance on the growth of $R E F$ cell line, this selectivity may be attributed to the metabolic behavior possessed by cancer cells rather than in normal cells such as metabolic nature to form new blood vessels, the shape and nature of the receptors presents on the surface of cancer cell and the ability to bind with different compounds [24]. In addition, in cancer cells DNA strands are relaxant and the whole molecule is unstable due to the distance between the hydrogen bonds (H-bonds) that bind the two strands together this facilitates the binding of intra- and extra-compounds with DNA strands while in normal cells DNA molecule is cohesive and $\mathrm{H}$-bonds are close to each other this prevent the binding of other foreign compounds [25]. 


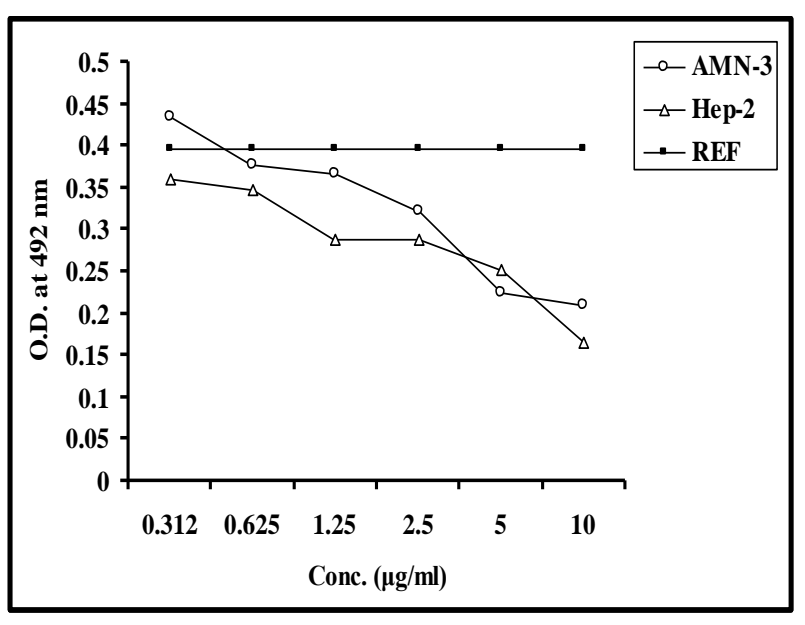

Fig. (3) The cytotoxic effect of CWP crud extract on AMN-3 and Hep-2 tumor cell lines and its effect on normal rabbit embryo fibroblast (REF) cell line after incubation period for 72 hrs.

\section{Conclusions}

Cell wall proteins of $L$. lactis possess conspicuous cytotoxic effect in growth inhibition of $A M N-3$ and Hep-2 tumor cell lines in vitro depending on both concentration and time. On the other hand, CWP have no cytotoxic effect with observed significance differences in the growth of normal rabbit embryo fibroblast $(R E F)$ cell line.

\section{References}

[1] Bralley, J. A.; Lord, R. S. "New Laboratory Measures for Detection of Abnormal Microbial Growth"; 76, 376-390, 2005.

[2] Dunne, C.; O'Mahony, L.; Murphy, L.; Thornton, G.; Morrissey, D.; O'Halloran, S.; Feeney, M.; Flynn, S.; Fitzgerald, G.; Daly, C.; Kiely, B.; O'Sullivan, G. C.; Shanahan, F.; Collins, J. K. "In vitro selection criteria for probiotic bacteria of human origin: correlation with in vivo findings"; Am. J. Clin. Nutr. 73, 386-392, 2011.

[3] Burns, A. J.; Rowland, I. R. "Anticarcinogenicity of probiotics and prebiotics"; Curr. Issues Intest. Microbiol. 1, 13-24, 2009.

[4] Macfarlane, G. T.; Cummings, J. H. "Probiotics and prebiotics: can regulating the activities of intestinal bacteria benefit health? Education and debate"; B. M. J. 318, 999-1003, 2008.
[5] Seegers, J. F. "Lactobacilli as live vaccine delivery vectors: progress and prospects"; Trends Biotechnol. 20, 508-515, 2007.

[6] Drouault, S.; Juste, C.; Marteau, P.; Renault, P.; Corthier, G. "Oral treatment with Lactococcuslactis expressing Staphylococcus hyicus lipase enhances lipid digestion in pigs with induced pancreatic insufficiency"; Appl. Environ. Microbiol. 68, 3166-3168, 2002.

[7] Harrigan, W. F.; McCane, M. E. "Laboratory methods in foods and dairy microbiology"; Academic Press London, 1976.

[8] Garvie, E. I. "Genus Leuconostoc. In: Bergeys Manual of Systematic Bacteriology". Sneath, P. H. A.; Mair, N. S. and Hold, J. G. (eds.). Williams and Wilkinsco, 2 Baltimore. M. D. USA. 1986.

[9] Al-Dulaimy G. A. "Using ethanol for isolation of lactic acid bacteria and studying synergistic effect with baker's yeast against some test bacteria". MSc thesis Dept. Food Technol, College of Agriculture, Uni of Baghdad. 2000.

[10] Henrich, B.; Binishofer, B.; Blasi, U. "Primary structure and functional analysis of the lysis genes of Lactobacillus gasseri bacteriophage fadh"; J. Bacteriol. 177, 723732, 1995.

[11] Bradford, M. M. "A rapid and sensitive method for the quantitation of microgram quantities of protein utilizing the principle of protein-dye binding"; Anal. Biochem. 72: 248-54, 1976.

[12] Freshney, R. I. "Culture of animal cells:

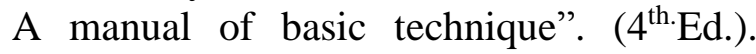
Wiley-Liss, A. and Wiley, J. (eds.). Inc. publication. New York, USA. P. 132-135. 2008.

[13] AL-Mohammed, N. T.; AL-Rawi, K. M.; Younis, M. A.; AL-Morani, W. K. Principles of statistics. Al-Mosil University. 1986.

[14] Chapman, H. R.; Sharpe, M. E. "Microorganism in Cheese. In: Dairy Microbiology". (2 $2^{\text {nd. Ed. }) . ~ R o b i n s o n, ~ R . ~ K . ~}$ (ed.). Applied Science Publishers. London and New Jersey 1981.

[15] Kandler, O.; Weiss, N. "Genus Lactobacillus. In: Bergeys Manual of Systematic Bacteriology. Sneath, P. H. A.; 
Mair, N. S.; Hold, J. G. (eds.) Vol 2, William and Wilkins co, Baltimore MD, USA. 1986.

[16] El Soda, M.; Ahmed, N. Omran, N. Osman, G.; Morsi, A. "Isolation, identification and selection of lactic acid bacteria cultures for cheesemaking"; Emir. J. Agric. Sci. 15, 51-71, 2009.

[17] Hayes, F.; Caplice, E.; Mcsweeney, A.; Daly, C. "PAMB1 Associated mobilization of proteinase plasmids from Lactococcus lactis UC317 and Lactococcus lactis sp. UC205"; Appl. Environ. Microbiol. 56, 195-201, 2001.

[18] Misawa, S.; Aoshima, M.; Takaku, H.; Matsumoto, M.; Hayashi, H. "High-level expression of Mycoplasma arginine deiminase in Escherichia coli and its efficient renaturation as an anti-tumor enzyme"; J. Biotechnol. 36, 145-155, 2004.

[19] Teuber, M. "The Genus Lactococcus. In: The Genera of Lactic Acid Bacteria". Wood BJ, Holzapfel WH. (eds.) 1995.

[20] Ivanova, K. Kabadjova, A.; Panter, A.; Danova, S.; Dousset, X. "Detection, purification and partial characterization of a noval, Bacteriocin subsp. Lcatis B14 isolated from Bosa-Bulgarian Traditional cereal Beverages: Biocatalysis"; Fundamen. and appl. 41, 47-53, 2000.

[21] Degnan, B. A.; Fontaine, M. C.; Doebereiner, A. H.; Lee, J. J.; Mastroeni, P.; Dougan, G.; Goodacre, J. A.; Kehoe, M. A. "Characterization of an isogenic mutant of Streptococcus pyogenes Manfredo lacking the ability to make streptococcal acid glycoprotein"; Infect. Immun. 68, 24412448, 2000.

[22] Curran, T. M.; Lieou, J.; Marquis, R. E. "Arginine deiminase system and acid adaptation of oral streptococci"; Appl. Environ. Microbiol. 61, 4494-4496, 1995.

[23] Grimm, M. C.; Pavli, P.; deVan, P. E. "Evidence for a CD14+ population of monocytes in inflammatory bowel disease mucosa-implications for pathogenesis"; Clin. Exp. Immunol.100, 291-297, 1995.

[24] Sekine, K.; Watanabe-Sekine, E.; Ohta, J.; Toida, T.; Tatsuki, T.; Kawashima, T. "Induction and activation of tumoricidal cells in vitro and in vivo by the bacterial cell wall of Bifidobacterium infantis. Bifidobacteria and Microflora"; 13, 65-77, 1994.

[25] Belijanski, M. "The anticancer agent PB100 selectivity active malignant cell inhibits multiplication of sixteen malignant cell lines, even multidrug resistant"; Genet. Mol. Biol. 23: 224-235, 2002.

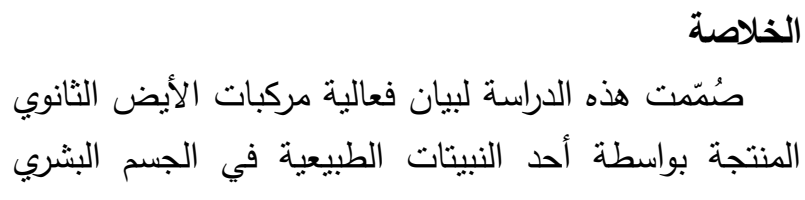

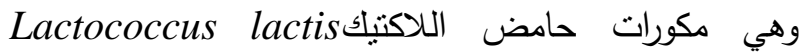

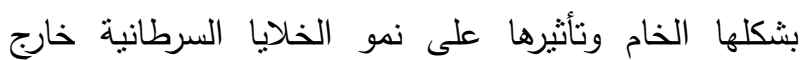

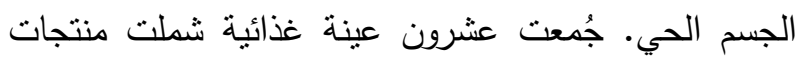
الألبان (اللبن الرائب الريفي والحليب المبستر والحليب الخام)، وعزلت منها تسع عزلات تعود للجنس Lactococcus نم عزلها باستخدام الوسط الزرعي MRS السائل ثم أَخضعت فعلت العزلات للفحوصات الدجهرية والزرعية فضلا عن الاختبارات

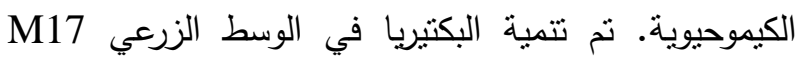

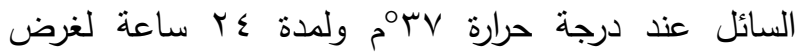
استخلاص بروتينات جدارها الخلوي باستخدام طريقة الصعق

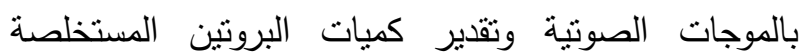

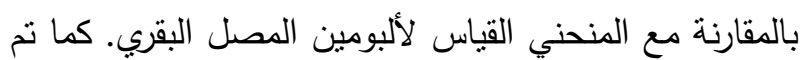

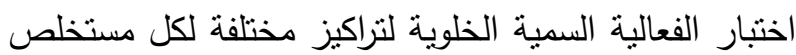

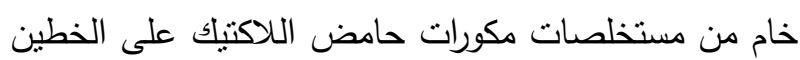
الخلويين السرطانيين AMN-3 و Hep-2 وبثلاث فترات

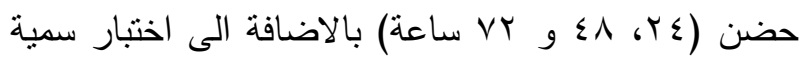
هذه المستخلصات الخام على الخط الخلوي الطبيعي لجنين الأرنب REF ولفترة حضن واحدة فقط وهي VY لأل ساعة.

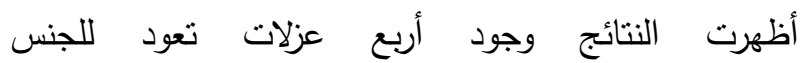
Lactococcus

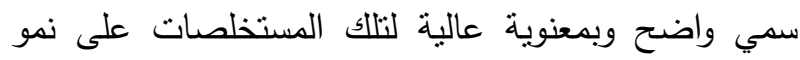
الخلايا السرطانية وخلال فترات الحضن الثنلاث، وقد لوحظ

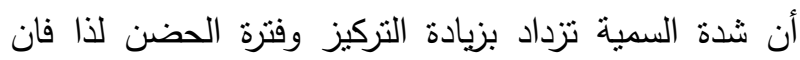

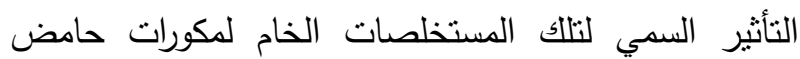
اللاكتيك يعتمد على التركيز وفترة الحضن، في حين لم يكن هناك تأثير واضح وذو معنوية لنفس المستخلصات في نمو الخلايا الطبيعية REF. قد يكون للمركبات الأيضية لمكورات

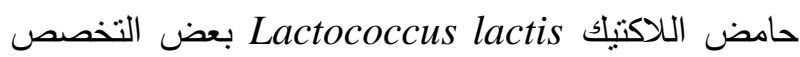
في التأثير السمي على نمو الخلايا السرطانية دون الطبيعية. 